\author{
MARTIN ŠTEFKO \\ ORCID: 0000-0003-1060-6682 \\ Charles University
}

\title{
CZECH UNDERSTANDING OF SOCIAL RISKS AND THEIR LIMITATIONS*
}

\begin{abstract}
This paper analyses the conception of social risks in Czech social security law in the last three decades. The Czech Republic spends a large proportion of its revenue on welfare of its citizens, who rely on the state's paternalistic care in return. Over time, benefits are increased and requirements are further softened. However, as we will see in chosen examples from healthcare, workers' compensation, and additional savings schemes, Czech experts are reluctant to answer new challenges with reformed instruments. Rules are hardly adapted to current issues, because the government tends to rely on old solutions. The government is unable to find a constructive platform to negotiate crucial social reform laws with the opposition.
\end{abstract}

Keywords: social security law, workers' compensation

Those who know only one country, know no country. ${ }^{1}$

\section{INTRODUCTION}

The old aim of laissez-faire philosophy has been largely forgotten in the Czech Republic, and in Czech social security law as well. In our global age, governments and local authorities are now obsessed with the need to achieve a high level of industrial investment, low level of unemployment, and better social welfare. The legal predecessor of the Czech Republic (the state of Czechoslovakia) ratified ILO Convention No. 102 with rather minor objections towards unemployment benefits and workers' compensation. The Czech legislature followed this convention in its many social reforms executed after the fall of Communism. However, respected scholars and other legal experts who have pondered social security law conceive

* This article has been written and published thanks to the financial support of the grant project "Soukromé právo a výzvy dneška" [Civil Law and Challenges of the Day], identity code Q03.

${ }^{1}$ M.L. Seymour, American Exceptionalism: A Double-Edged Sword, New York 1996, p. 17. 
that social risks are strongly influenced by local living and working conditions, legal traditions, specific historical developments and political decisions (as will be briefed in sections 1 and 2 of this article).

Czech politicians argue that economic policy should benefit the majority of the country's citizens. However, when it comes to the shift towards smaller governments and freer markets over the last two decades, the evidence indicates that this has not been the case in many countries. ${ }^{2}$ While the financial recession has highlighted the need for greater government intervention to stimulate economies and prevent future financial crises, the stagnation of wages and the growth of inequality indicate that a broader return of the state is necessary. In section three of this article, we will analyse some social reforms that intended to execute structural legislative changes, which may be linked to Czech social security law. Some of them were broadly holistic, intended to meet the financial crises the Czech Republic was confronted with, whereas others (the majority) are merely small-scale measures to rationalise the system. Out of all the important changes, this article will map only one reform pattern. Speaking about large-scale changes, we can trace some common reform patterns compared to the situation in Europe. The most important are attempts to stand ground - the desire to defend local developments (e.g. workers' compensation and additional old-age savings schemes). Something that is by no means new.

\section{UNDERSTANDING OF SOCIAL CONTINGENCIES}

The origins of the modern systems of social security in the Czech Republic are found in both the Austrian Empire and the Soviet Union. As to the former, the Czech social assistance system was established in the 1850s, and at the end of the century social insurance was introduced through so-called Taafe's reform, which was strongly inspired by Bismarckian social reforms in Germany. As to the latter, the whole system inherited from the Austrian Empire and developed during the First Czechoslovak Republic (1918-1938) was subsequently centralised and followed the Soviet model of social security. During the 1950s and 1960s, all private areas of social security — including the system of social assistance - were abolished; social security as such was run by the state and its institutions (including also social services); and the citizen was only socially secured by the state, regardless of his/her contribution to social welfare.

Shortly after the political changes in November 1989 - still in former Czechoslovakia - economic reform commenced, accompanied by an extensive

2 J. Pichrt, K. Koldinská, "The right to social security in the Constitution of the Czech Republic", [in:] The Right to Social Security in the Constitutions of the World: Broadening the Moral and Legal Space for Social Justice, eds. A. Jegorov, M. Wujczyk, Geneva 2016, p. 31. 
and fundamental reform of the legal system. Surprisingly enough, academics were able to persuade the respective authorities to prepare also a programme of social reform. In fact, on the same day that the so-called scenario of economic reform was presented, the 'scenario of social reform' was proposed as well. In the Czech version of the reform scenario, economic reform could not be performed successfully without social reform.

The new concept of social security (introduced gradually after 1989) represents a transition from state paternalism to the participation and responsibility of citizens and social groups for their social situation and future. It is based on the principle that citizens and families must ensure the widest possible scope of their needs on a socially acceptable level through their own efforts. The state should interfere only where the citizen or the family cannot manage, for subjective or objective reasons. The state, however, must guarantee citizens' security on a dignified level, as many sources of international and EU law on fundamental social rights provide. ${ }^{3}$

\section{CZECH SOCIAL SECURITY FRAMEWORK}

Czech social security law is composed of four main pillars as follows: social insurance law (public pension insurance, sick leave insurance, healthcare, old-age supplementary schemes), public employment policy, state social assistance, and social assistance.

Pension insurance is regulated in Act No. 155/1995 Coll. on Pension Insurance. Wage-earners ('employees' in Czech legislation), like other persons performing work or similar activities, are entitled to an old-age, invalidity, widow's or widower's and orphan's pension. Under sick leave insurance, the insured are compensated for maternity leave, temporary disability to work, short-term care and long-term care.

A specific feature of the Czech social security system is the separation of health insurance from sickness (or social) insurance, both in respect of its codification, organisation, and implementation, and its financing and administration. Healthcare carriers are obliged to finance healthcare provided to the insured.

Czech law does not regulate unemployment insurance, but citizens and other privileged aliens are protected by a modest benefits scheme in Act No. 435/2004 Coll., the Employment Act, as amended. Said act regulates placement services, which are provided (mostly to unemployed persons) by labour offices, and, if necessary, state unemployment benefits paid to unemployed persons during the time when they are unemployed, including the amount of the benefits, and duration of the support period.

${ }^{3}$ K. Koldinská et al., Právo sociálního zabezpečení) [Social Security Law], Praha 2018, p. 3. 
Employees' compensation for injury caused by occupational accidents or occupational diseases is still regulated in the Labour Code (concretely in accordance with Sections 365-393 of the Labour Code) and on the basis of the principle of liability of the employer for damage caused by occupational accident or occupational disease.

Family allowances are regulated in Act No. 117/1995 Coll., on state social support. This system was introduced in 1995, whereas previously family benefits were covered under the system of social security. Under state social support, the following benefits are available: child allowance, housing allowance, parental allowance, foster care benefits, birth grants, and funeral grants.

Social assistance is guaranteed by a trinity of laws: Act No.111/2006 Coll., on assistance in material need, Act No. 108/2006 Coll., on social services, as amended, and Act No. 329/2011 on benefits for disabled persons, as amended. The Act on assistance in material need regulates a modern system to assist those with insufficient income; the system motivates them to actively strive to secure the resources they need to meet their living requirements. It is one of the means applied by the Czech Republic to combat social exclusion. The Act as a whole is based on the principle that 'all persons who work must be better off than those who are out of work or who avoid work'. The Act on assistance in material need defines situations of inadequate means of subsistence or housing, and defines some emergencies. The system helps to deal with certain special circumstances that can only be resolved with immediate assistance. The Act sets the rule that everyone is entitled to receive basic information that can not only address their particular material need, but also prevent it from occurring in the first place. Social work with clients is an integral part of the system of assistance in material need.

\section{NEW SOCIAL RISKS AND LEGISLATIVE RESPONSES}

In this section, we will analyse three social contingencies that have been brought to the legislature's attention in the last three decades. The stakeholders have to react and they did so.

\subsection{HOME-BIRTHS}

Given the evidence that home-birth is both safe for normal births, and cheaper than a hospital birth, it should be hard for a Czech health authority to argue that providing a home-birth service is not in a woman's best interests, or that it is not an effective use of resources. ${ }^{4}$ However, despite that, state policy is geared against

4 The author of this paper does not wish to either promote or condemn planned unassisted birth; rather the aim of this section is simply to inform about Czech regulations, practice and test cases. 
home-birth. The Czech legislature set forth such onerous requirements for homebirth as to effectively negate the possibility of having a home-birth. Although there are no laws forcing a woman to go to hospital to give birth - so every woman has the right to insist that she is staying at home to have her baby - she is as a result of said state policy not able to reach any home-birth service.

This serious reduction in the rights of users of healthcare apparently occurred without much debate and with little comment from the government. It has been suggested that, if this change in the law took place without sufficient debate, it will soon be the subject of judicial review. This is exactly what happened on both the national and international level, as examined below.

The Supreme Court of the Czech Republic upheld ${ }^{5}$ that the described state policy is lawful. The plaintiff brought a maladministration claim against the state as it did not ensure care during home-births, and had not enacted the necessary legislation. As a result, the plaintiff had to give birth at home without qualified care. The courts of the first and second instance dismissed the claim.

The plaintiff appealed on the grounds that the courts omitted to consider Art. 8 of the Convention on the Protection of Human Rights and Fundamental Freedoms and Art. 10 para. 2 of the Charter of Rights and Freedoms. She also contended that the Czech Republic had paid lip service to the Parliament and Council Directive No. 2005/36/EC as well as Council Directive No. 80/155/EEC, which deals with the activities of midwives at home-births. She further contended that the Czech Republic acted in breach of its obligations under EU law and that constituted maladministration.

The Supreme Court confirmed settled practice and stated that, as a matter of principle, the legislative activity is not considered as maladministration, which applied also to the government's statutes. The Supreme Court stated that there was no rule in Czech legislation that would have ordered the health authorities to provide a home-birth service, and the obligation cannot be deduced from Art. 8 of the Convention as well. The court further came to the conclusion that no article of Council Directive No. 80/155/EEC imposed a duty to ensure medical care for pregnant women during home-births by midwives, and that the Czech legal regulation enabling midwives to help women during births in healthcare institutions did not contradict said directive. The EU law was adopted to eliminate discrimination against midwives coming from individual member states of the European Union on the basis of nationality, and to ensure their free movement and freedom of settlement, and not to determine conditions for providing medical services.

This case must be considered as a matter of fact that if a woman sought judicial review of a health authority's refusal to provide a home-birth service, she might not be in a good position because there is no legal right for a woman to insist upon a home-birth. Czech legislature assumes that a hospital birth is always better,

5 Supreme Court judgement of 15 June 2016, file number 30 Cdo 3598/2014. 
even if a woman can show that it is not in her best interests and that the resource implications are in the national health care insurance scheme's favour.

The European Court of Human Rights upheld the Czech regulations in question, in Dubska and Krejzová v. the Czech Republic (application nos. 28859/11 and 28473/12). The court examined three main factors in order to evaluate the measures adopted by the national authorities to deal with those risks: whether they gave due weight to the competing interests and whether they carefully considered the possible alternatives and assessed the proportionality of their policy in respect of home-births. It was the legislative and administrative framework that was in fact appraised in said case.

\subsection{WORKERS' COMPENSATION}

Compulsory insurance was established at the beginning of the 1990s above all as a reaction to the development of small and middle-sized businesses in the Czech Republic (after the fall of socialism) and as a reaction to a rise in doubts about whether smaller enterprises would be economically strong enough to cope with the financial impact of the consequences of occupational accidents of their employees. For that reason the risk (endangering injured employees but also employers themselves - above all smaller ones) has been transferred to insurance companies by virtue of the institution of compulsory insurance. All employers who employ at least one employee (excluding an employer who is a structural unit of the state) ${ }^{6}$ must be ex lege insured for liability for damage in case of occupational accident or occupational disease. The employer's obligation to arrange contractual insurance according to special legal regulations is extinguished if it is covered by compulsory insurance. If rights and duties ensuing from the industrial relationship are not transferred to another employer in case of an employer's termination, the injured person (survivor) has the right to be paid compensation directly by the insurance company to the same extent as the insured employer should pay him.

When Act no. 266/2006 Coll., the Accidents Insurance Act, ${ }^{7}$ becomes effective (this Act is in abeyance so far; its coming into force was last postponed until 1 January 2015; the reasons for postponement are of a conceptual and fiscal character) the present concept of liability for damage (which emphasises above all prevention of these negative features by virtue of liability of the employer) will be abolished and matters relating to liability for occupational accidents and occupational diseases will be regulated under the system of accident insurance. Until the Accidents Insurance Act becomes effective the present Labour Code in principle

${ }^{6}$ For determination of a structural unit of the state consider Section 3 of Act no. 219/2000 Coll., on the property of the Czech Republic and its acting in legal relations.

7 The Act envisages the establishment of a new system of accident insurance, run by the CSSA. Employers should contribute substantially to this system, and in case of work accidents, several benefits could be claimed by the worker. 
has adopted the conception of the previous Labour Code (Act no. 65/1965 Coll., as amended); the present Labour Code (in Sections 365-393) has in principle adopted similar provisions of the previous Labour Code. Matters concerning the compulsory insurance of an employer against damage caused by occupational accident or occupational disease are still governed by Section 205(d) of the previous Labour Code until the Accidents Insurance Act becomes effective.

In 2014, the Act on Occupational Accident Insurance of 2006 was abolished. The Czech legislature prefers to solve issues regarding occupational injuries within the realm of labour law. The current scheme is neither the German approach with self-governed insurance associations funded by employers' contributions, nor the second state-administered scheme where the system for compensating occupational injuries and disease as part of its wider provision for social security levies contributions from employers to finance it. It is a mix of public insurance operated by only two domestic insurance companies and the civil tort liability of an insuree's employer.

Czech legislative practice is to hold consultations with all stakeholders over a modest period during the development of policy proposals, so that they have input at the substantive policy formation stage. Consultations are conducted in line with the Government Legislative Code of Practice on Consultation (in Czech "Legislativní pravidla vlády"). The government prepared a set of ideas for the new law at the beginning of 2017 (for internal purposes) and presented it to the public in May and June 2017. ${ }^{8}$ The previous plan that the new law should come into effect in 2020 has been abandoned after the EU represented that the current Czech labour law model does not breach EU competition law.

The new Czech Civil Code, which entered into force on 1st January 2014, without doubt influenced workers' compensation substantially. Not surprisingly enough, the day-to-day application of the new code has revealed a number of shortcomings practitioners find difficult to face. The most serious obstacles for the Civil Code's bright future ahead are doubts connected with remedies for occupational health injuries.

The legislation aimed to free courts from tables they had to apply when evaluating harm suffered to an individual's health. The Civil Code established in Section 2958 that harm (for example pain and lower employability) shall be compensated in full on the basis of equity ("as it is fair"). In addition, the Civil Code abolished the ministerial decree (Decree No. 440/2001 Collection) that defined the evaluation method based on tables. Despite years of preparation, the officials who prepared the Civil Code forgot to annul Section 394 of the Labour Code. This provision sets forth that Decree No. 440/2001 Collection shall continue to apply until

8 Cf. http://www.komora.cz/pro-podnikani/legislativa-a-normy/pripominkovani-legislativy/ nove-materialy-k-pripominkam/115-16-navrh-vecneho-zameru-zakona-o-pojisteni-odpovednosti-zamestnavatele-za-skodu-pri-pracovnim-urazu-t-7-6-2016.aspx (accessed: 26.06.2019). 
the law on occupational accidents insurance comes into force. Meanwhile, the Ministry of Labour and Social Affairs in cooperation with the Ministry of Health issued a declaration that Decree No. 440/2001 Collection shall be applied. This declaration was to a certain degree supported by the Supreme Court's statement that the decree should be respected by courts in civil proceedings. Although the legal situation was not clear, the legislature found the solution almost two years later on 26th October 2015, when a new Government Regulation on Workmen's Compensation (No. 276/2015 Collection) was published. It should not be a surprise that the old tabular method was upheld to a large degree.

\subsection{ADDITIONAL OLD-AGE SAVINGS SCHEMES}

Czech society is ageing, the size of the working population is shrinking and public pension insurance is in the red. The state had to take action to ensure that the pension system remains on an adequate and sustainable footing. The long awaited second pension reform phase began in the Czech Republic in 2009. In order to finalise the whole process, a third phase was envisaged. The government promised to offer a chance for an opt-out of the compulsory system on a larger scale.

In contrast to expectations, the public rather neglected the new pension savings system. According to data from July 2013, only a small percentage decided to participate in the system of additional pension savings programme (on 23rd July 2013 , the overall number was $\left.78,500^{9}\right)$. Furthermore, this number, which was low in any case, was divided between 10 pension companies, who created a product that was economically not self-sufficient. ${ }^{10}$

In addition, the number of participants was not expected to rise too rapidly in the absence of a consensus across the parliamentarian political parties regarding the specific shape of pension reform. The second reason for the apparent failure of the reform was the mass participation in the supplementary pension insurance scheme that has been partially amended and partially terminated by the reform. Almost half of the 10 million inhabitants in the Czech Republic participate in this system. ${ }^{11}$

The government did not bother to negotiate at least a basic consensus with the opposition and pushed the respective laws through the Parliament by force. Hence, Necas as the prime minister shaped the recent pension reform without a consensus

9 See http://www.finance.cz/zpravy/finance/394624-do-2-pilire-penzijniho-systemu-vstoupi lo-za-pul-roku-78-500-lidi/ (accessed: 14.09.2019).

10 The provision of $\S 30$ of the Pension Savings Act defines that the number of participants in pension funds operated by pension companies has to reach at least 50,000 participants within 24 months from the date on which the permission to create a pension fund is granted. You can look up the number of participants in individual pension instance companies at http://www.produktovelisty.cz/penze/clanky/577-penze-v-pololeti-co-prozradi-vysledky.html (accessed: 14.05.2019).

${ }^{11} C f$. http://www.mfcr.cz/cps/rde/xchg/mfcr/xsl/ft_ukazatele_penzijniho_pripojisteni_72156. html (accessed: 22.04.2019). 
reached across the parliamentarian political parties. As a result, its opposition had repeatedly informed the government, pension insurance companies as well as the wider public that, after a victory in the parliamentarian elections, it intended to abolish the pension savings system.

In the House of Commons parliamentary elections, which were held in October 2013, the right (in particular the historically dominant Civic Democrats, in Czech abbreviated as "ODS") experienced a huge defeat, as many of its voters switched to the ANO, which purported to be pro-business. The Social Democrats, which had expected a far stronger victory, took only $21 \%$ of the vote, followed by the ANO with $19 \%$ and the Communists with $15 \%$. The right-centre TOP 09 and ODS got $12 \%$ and $8 \%$ respectively. Usvit (Dawn), a party some term proto-fascist, scored 7\%, as did the Christian Democrats. The Social Democrats had hoped to secure at least 70 seats in the 200-seat Chamber of Deputies, but instead won just 50 . After weeks of negotiation, a coalition was forged between the Social Democrats, ANO and the Christian Democrats. Now, the opposition became the government and started to seek ways how to reverse the current supplementary retirement insurance scheme, much to the public's disappointment.

In the coalition agreement, the new Government stated explicitly that it would prepare a proposal to terminate the system of pension savings (the so-called " 2 nd pillar"). An expert committee (most often translated as "the Professional Committee for Pension System Reform") was set up consisting of delegates of coalition and opposition parties, as well as representatives of the social partners and other experts in order to arrive at a broader consensus on the way forward for the reform of the pension system. Despite threatening disputes on compensation to investors, insurance companies, and citizens, the government decided to abolish the 2nd pillar in January 2016. The respective statute was approved in October 2015 and the law came into force on 1st January 2016. The insurance rates were returned to the status quo before the introduction of the second pillar, i.e. the insurance rate for all employees was assigned again at $6.5 \%$ (from the assessment base). The rate for employers remained unchanged. For self-employed persons who participated before 1 January 2016 in pension savings the insurance rate of $29.2 \%$ (from the assessment base) became valid.

The Expert Committee on Pension Reform also made some recommendations to the remaining system of supplementary pension savings in order to alter it into a real additional source of income in old age. The Committee proposed a tax exemption for pensions paid out for more than 10 years, similarly as in the case of statutory pensions. Furthermore, the system needed to be adjusted to allow for higher equities (returns) for participants in order to accumulate sufficient capital for their old age security. For this reason, certain strict limits on investing should have been alleviated and the range of investment instruments should have been expanded. ${ }^{12}$

$12 C f$. http://www.duchodova-komise.cz/?page_id=1248 (accessed: 3.03 .2019 ). 
Private pension savings is a vital element in ensuring that retirement incomes are adequate and that state pension provision remains sustainable into the future. Even so, the government abolished the system of pension savings (the so-called "2nd pillar"). The respective Act 376/2015 Collection was approved in October 2015 and the law came into force on 1st January 2016. ${ }^{13}$

\section{CONCLUSION}

In some countries, not parliaments but other institutions played a pivotal role in executing decisions on social risk soothing tools. Experts and MPs perceived many health risks connected with home-births. It was their perception of health risks which shaped the ambiguous Czech official policy applied to home-births. In the end, every woman has the virtual right to insist that she is staying at home to have her baby, but as a result of the described state policy, very few women can be covered by a home-birth service.

The second analysed example is harder to explain. The preservation of a weird mix of Soviet strict employer liability and public insurance policy seems to work in favour of two privately owned insurance companies, which are entrusted with fixed profits guaranteed by law. However, it is true that the scheme entitles harmed employees with the right to receive full compensation, but without any compensation for rehabilitation.

The third case is easier to explain. Two egos and two prime ministers confronted each other. Contrary to the proposal of the Expert Committee on Pension Reform, democratic principles and political dialogue had always been difficult to find. The Czech political scene was unable to maintain a constructive dialogue, despite what was at stake. Politicians made from the additional savings scheme a clear example for future generations that the state's plans are neither sound, nor clear. Regardless of what reform law will be eventually prepared, the public has lost confidence and it will take years to regain it. The opposition prioritised improvements in the social situation of the population over the long-term sustainability of the pension system at the moment of the election of the incoming Parliament.

As we attempted to describe, important choices were executed undemocratically by few people, which is problematic since the debts arising from these decisions will be shared by all tax and social security payers. Every economy is naturally unstable, and the state's revenue from taxes and other payments is largely unpredictable; therefore social protection is better regulated through ordinary statutes in accordance with economic laws and a balanced governmental budget. The apparent imbalance in most European states, the Czech Republic included,

13 In Czech: zákon č. 376/2015 Sb. o ukončení důchodového spoření. 
has to be settled and it is obvious that there is no magic solution. We must launch an austerity programme, because the opportunity costs would otherwise be great. States in the red have no other option than to execute draconian measures, such as high taxation, retroactive changes of requirements for pensions, or lowering of already adjudicated pensions.

\section{CZESKIE ROZUMIENIE RYZYK SOCJALNYCH I ICH GRANIC}

\section{Streszczenie}

Artykuł zawiera analizę koncepcji ryzyka socjalnego w czeskim prawie zabezpieczenia społecznego w ciągu ostatnich trzech dekad. Republika Czeska wydaje znaczną część swoich dochodów na zapewnienie dobrobytu swoich obywateli, którzy w zamian polegają na paternalistycznej opiece państwa. Z biegiem czasu korzyści rosną, a wymagania ulegają dalszemu złagodzeniu. Jednak wybrane przykłady z zakresu opieki zdrowotnej, odszkodowań pracowniczych i dodatkowych programów oszczędnościowych pokazują, że czescy eksperci niechętnie odpowiadają na nowe wyzwania za pomocą zreformowanych instrumentów. Obowiązujące przepisy są słabo dostosowane do bieżących problemów, ponieważ rząd zwykle polega na starych rozwiązaniach. Rząd nie jest też w stanie znaleźć konstruktywnej platformy do negocjowania z opozycją kluczowych rozwiązań z zakresu zabezpieczenia społecznego.

Słowa kluczowe: prawo zabezpieczenia społecznego, odszkodowanie dla pracowników

\section{BIBLIOGRAPHY}

Beveridge F., "Unequal treatment in social security law: Objective justification", Childcare and the English Courts, in Journal of Social Security Law 13, 2006, no. 1, pp. 31-46.

Koldinská K. et al., Právo sociálního zabezpečeni [Social Security Law], Praha 2018.

Koldinská K., Štefko M., Sociální práva cizinců [Welfare Rights of Foreigners], Prague 2013.

Pennings F., Introduction to European Social Security Law, second edition, The Hague 1998.

Pichrt J., Koldinská K., "The right to social security in the Constitution of the Czech Republic", [in:] The Right to Social Security in the Constitutions of the World: Broadening the Moral and Legal Space for Social Justice, eds. A. Jegorov, M. Wujczyk, Geneva 2016, pp. 31-45.

Pichrt J., Štefko M., Labour Law and Industrial Relations - Czech Republic, Alphen aan den Rijn 2015.

Supreme Court of the Czech Republic judgment of 15th June 2016, file number 30 Cdo 3598/2014. 